\title{
Putting the Parts Together: Trade, Vertical Linkages, and Business Cycle Comovement WEB APPENDIX
}

\author{
Julian di Giovanni \\ International Monetary Fund
}

\author{
Andrei A. Levchenko \\ University of Michigan \& \\ International Monetary Fund
}

July 23, 2009 
Appendix A Supplementary Tables 
Table A1. Country Summary Statistics: 1970-99

\begin{tabular}{|c|c|c|c|c|c|}
\hline Country & $\begin{array}{c}\text { Average } \\
\text { correlation }\end{array}$ & $\begin{array}{c}\text { Trade/ } \\
\text { GDP }\end{array}$ & Country & $\begin{array}{c}\text { Average } \\
\text { correlation }\end{array}$ & $\begin{array}{c}\text { Trade/ } \\
\text { GDP }\end{array}$ \\
\hline Australia & 0.128 & 0.175 & Bangladesh & 0.101 & 0.120 \\
\hline Austria & 0.161 & 0.427 & Bolivia & 0.099 & 0.230 \\
\hline Belgium-Luxembourg & 0.247 & 0.874 & Chile & 0.152 & 0.268 \\
\hline Canada & 0.195 & 0.369 & Colombia & 0.233 & 0.163 \\
\hline Denmark & 0.175 & 0.421 & Costa Rica & 0.182 & 0.383 \\
\hline Finland & 0.156 & 0.409 & Cyprus & 0.170 & 0.571 \\
\hline France & 0.271 & 0.265 & Ecuador & 0.134 & 0.192 \\
\hline Greece & 0.214 & 0.240 & Egypt, Arab Rep. & -0.047 & 0.222 \\
\hline Ireland & 0.145 & 0.734 & Fiji & 0.121 & 0.522 \\
\hline Italy & 0.272 & 0.266 & Guatemala & 0.057 & 0.231 \\
\hline Japan & 0.253 & 0.139 & Honduras & -0.018 & 0.436 \\
\hline Netherlands & 0.226 & 0.672 & Hong Kong, China & 0.135 & 1.278 \\
\hline New Zealand & 0.021 & 0.351 & Hungary & 0.059 & 0.414 \\
\hline Norway & 0.180 & 0.368 & India & 0.030 & 0.081 \\
\hline Portugal & 0.197 & 0.363 & Indonesia & 0.103 & 0.238 \\
\hline Spain & 0.258 & 0.197 & Israel & 0.138 & 0.352 \\
\hline Sweden & 0.131 & 0.421 & Jordan & 0.064 & 0.388 \\
\hline United Kingdom & 0.169 & 0.325 & Korea, Rep. & 0.169 & 0.384 \\
\hline \multirow[t]{18}{*}{ United States } & 0.231 & 0.109 & Malawi & -0.073 & 0.250 \\
\hline & & & Malaysia & 0.115 & 0.830 \\
\hline & & & Malta & 0.113 & 1.047 \\
\hline & & & Mauritius & -0.057 & 0.686 \\
\hline & & & Mexico & -0.090 & 0.189 \\
\hline & & & Panama & -0.095 & 0.892 \\
\hline & & & Peru & 0.039 & 0.198 \\
\hline & & & Philippines & 0.021 & 0.352 \\
\hline & & & Senegal & 0.015 & 0.299 \\
\hline & & & Singapore & 0.238 & 1.926 \\
\hline & & & South Africa & 0.100 & 0.240 \\
\hline & & & Sri Lanka & -0.061 & 0.293 \\
\hline & & & Syrian Arab Republic & 0.097 & 0.180 \\
\hline & & & Tanzania & 0.166 & 0.181 \\
\hline & & & Trinidad and Tobago & 0.080 & 0.536 \\
\hline & & & Turkey & 0.027 & 0.160 \\
\hline & & & Uruguay & 0.117 & 0.211 \\
\hline & & & Zimbabwe & 0.059 & 0.131 \\
\hline Mean & 0.191 & 0.375 & & 0.095 & 0.354 \\
\hline
\end{tabular}

Notes: The first column reports the average correlation of real manufacturing output growth between a country and the rest of the countries in the sample. Trade/GDP is the average share of manufacturing trade of a country to its GDP over the period. 
Table A2. Subsample Summary Statistics for Manufacturing Sector: 1970-99

\begin{tabular}{lcccc}
\hline \hline Sample & & Average correlation & & Trade/GDP \\
\cline { 1 - 1 } Full & & 0.115 & 0.0011 \\
OECD/OECD & 0.397 & & 0.0036 \\
non-OECD/non-OECD & & 0.065 & 0.0011 \\
OECD/non-OECD & 0.091 & & 0.0005 \\
\hline
\end{tabular}

Notes: Average correlation is the sample average of bilateral correlation of manufacturing output growth. Trade/GDP is sample average of the share of total bilateral sectoral trade of two countries to their GDP. 
Table A3. Sector Summary Statistics: 1970-99

\begin{tabular}{|c|c|c|c|c|c|c|}
\hline ISIC & Sector name & $\begin{array}{c}\text { Average } \\
\rho_{i i}\end{array}$ & $\begin{array}{c}\text { Average } \\
\rho_{i j}\end{array}$ & $\begin{array}{c}\text { Trade/ } \\
\text { GDP }\end{array}$ & $\begin{array}{c}\text { Vertical } \\
\text { Intensity }\end{array}$ & $\begin{array}{l}\text { Upstream } \\
\text { Intensity }\end{array}$ \\
\hline 311 & Food products & 0.054 & 0.057 & 0.053 & 0.195 & 0.150 \\
\hline 313 & Beverages & 0.068 & 0.066 & 0.006 & 0.022 & 0.524 \\
\hline 314 & Tobacco & 0.029 & 0.027 & 0.005 & 0.105 & 0.082 \\
\hline 321 & Textiles & 0.133 & 0.087 & 0.022 & 0.313 & 0.481 \\
\hline 322 & Wearing apparel, except footwear & 0.093 & 0.064 & 0.020 & 0.106 & 0.678 \\
\hline 323 & Leather products & 0.034 & 0.046 & 0.003 & 0.273 & 0.517 \\
\hline 324 & Footwear, except rubber or plastic & 0.045 & 0.049 & 0.001 & 0.017 & 0.709 \\
\hline 331 & Wood products, except furniture & 0.076 & 0.080 & 0.008 & 0.323 & 0.204 \\
\hline 332 & Furniture, except metal & 0.078 & 0.082 & 0.002 & 0.014 & 0.571 \\
\hline 341 & Paper and products & 0.228 & 0.094 & 0.008 & 0.301 & 0.312 \\
\hline 342 & Printing and publishing & 0.069 & 0.064 & 0.003 & 0.081 & 0.685 \\
\hline 351 & Industrial chemicals & 0.126 & 0.086 & 0.030 & 0.421 & 0.192 \\
\hline 352 & Other chemicals & 0.095 & 0.075 & 0.014 & 0.141 & 0.355 \\
\hline 353 & Petroleum refineries & 0.079 & 0.063 & 0.036 & 0.084 & 0.060 \\
\hline 354 & Misc. petroleum and coal products & 0.040 & 0.040 & 0.001 & 0.012 & 0.498 \\
\hline 355 & Rubber products & 0.082 & 0.066 & 0.004 & 0.064 & 0.563 \\
\hline 356 & Plastic products & 0.131 & 0.093 & 0.004 & 0.070 & 0.570 \\
\hline 361 & Pottery, china, earthenware & 0.126 & 0.086 & 0.001 & 0.052 & 0.146 \\
\hline 362 & Glass and products & 0.119 & 0.091 & 0.002 & 0.088 & 0.282 \\
\hline 369 & Other non-metallic mineral products & 0.104 & 0.085 & 0.004 & 0.118 & 0.193 \\
\hline 371 & Iron and steel & 0.155 & 0.087 & 0.016 & 0.236 & 0.258 \\
\hline 372 & Non-ferrous metals & 0.150 & 0.086 & 0.015 & 0.606 & 0.195 \\
\hline 381 & Fabricated metal products & 0.109 & 0.076 & 0.014 & 0.103 & 0.433 \\
\hline 382 & Machinery, except electrical & 0.045 & 0.048 & 0.045 & 0.088 & 0.545 \\
\hline 383 & Machinery, electric & 0.068 & 0.053 & 0.031 & 0.327 & 0.268 \\
\hline 384 & Transport equipment & 0.071 & 0.047 & 0.107 & 0.368 & 0.580 \\
\hline 385 & Professional \& scientific equipment & 0.056 & 0.047 & 0.009 & 0.043 & 0.423 \\
\hline \multirow[t]{2}{*}{390} & Other manufactured products & 0.045 & 0.056 & 0.011 & 0.060 & 0.533 \\
\hline & AVERAGE & 0.090 & 0.068 & 0.017 & 0.165 & 0.393 \\
\hline
\end{tabular}

Notes: The first two columns report the average correlation of real sector-level output growth between a pair of countries, averaged over country pairs within a sector and with all other sectors of the economy, respectively. Trade/GDP is, for each sector, the average (across countries) of the share of sectoral trade of a country to its GDP. Vertical Intensity and Upstream Intensity are calculated from the BEA input-output matrix after aggregating up to the 28 manufacturing sectors for which there is production data. Vertical Intensity is the diagonal term of the I-O matrix. It represents the value of output of the sector needed as an intermediate input to produce a dollar of final output in that same sector. Upstream Intensity is the sum across rows for a given column of the I-O matrix, excluding the diagonal. It represents the value of output of all other sectors needed as intermediate inputs to produce one dollar of final output a given sector. 
Table A4. Estimates of the Impact of Total Bilateral Trade on Aggregate Comovement in Real GDP and Total Manufacturing Real Output

\begin{tabular}{|c|c|c|c|}
\hline & \multicolumn{3}{|c|}{ Aggregate } \\
\hline \multirow{5}{*}{ Trade } & Trade/ & Trade/ & Trade/ \\
\hline & $G D P$ & Output & Total Trade \\
\hline & $(1)$ & $(2)$ & (3) \\
\hline & $17.56^{* *}$ & $16.08^{* *}$ & $20.04^{* *}$ \\
\hline & $(3.59)$ & $(3.33)$ & $(3.59)$ \\
\hline Observations & 1967 & 1967 & 1967 \\
\hline \multirow[t]{5}{*}{$R^{2}$} & 0.383 & 0.383 & 0.385 \\
\hline & \multicolumn{3}{|c|}{ Manufacturing } \\
\hline & Trade/ & Trade/ & Trade/ \\
\hline & $G D P$ & Output & Total Trade \\
\hline & $(1)$ & $(2)$ & $(3)$ \\
\hline \multirow{2}{*}{ Trade } & $13.55^{* *}$ & $14.43^{* *}$ & $15.58^{* *}$ \\
\hline & $(3.95)$ & $(3.30)$ & $(3.86)$ \\
\hline Observations & 1496 & 1496 & 1496 \\
\hline$R^{2}$ & 0.465 & 0.467 & 0.467 \\
\hline$\mu_{c 1}+\mu_{c 2}$ & yes & yes & yes \\
\hline
\end{tabular}

Notes: Robust standard errors in parentheses. ${ }^{* *}$ significant at $1 \%$; ${ }^{*}$ significant at $5 \%$; + significant at $10 \%$. The sample period is 1970-99. The dependent variables are the correlations of the growth of real GDP (top panel) and the growth of real manufacturing output (bottom panel). All regressors are in natural logs. $\mu_{c 1}$ and $\mu_{c 2}$ denote the country fixed effects All specifications are estimated using OLS. 
Table A5. Impact of Trade on Comovement at the Sector-Level: All Specifications for HP-Filtered Data

\begin{tabular}{|c|c|c|c|c|c|c|c|c|}
\hline & & Specific & ation I & & & Specific & tion II & \\
\hline & $(1)$ & $(2)$ & $(3)$ & $(4)$ & $(1)$ & $(2)$ & $(3)$ & $(4)$ \\
\hline Trade & $7.24^{* *}$ & $4.05^{* *}$ & $3.71^{* *}$ & $2.75^{* *}$ & $7.11^{* *}$ & $3.92^{* *}$ & $3.57^{* *}$ & $2.62^{* *}$ \\
\hline & $(0.07)$ & $(0.10)$ & $(0.11)$ & $(0.12)$ & $(0.07)$ & $(0.10)$ & $(0.11)$ & $(0.12)$ \\
\hline Trade $\times$ Same Sector & - & - & - & - & $3.41^{* *}$ & $3.71^{* *}$ & $3.81^{* *}$ & $3.95^{* *}$ \\
\hline & - & - & - & - & $(0.39)$ & $(0.37)$ & $(0.34)$ & $(0.38)$ \\
\hline Same Sector & - & - & - & - & $108.31^{* *}$ & $116.39^{* *}$ & $118.47^{* *}$ & - \\
\hline & - & - & - & - & $(10.58)$ & $(9.88)$ & $(9.16)$ & - \\
\hline Observations & 653,588 & 653,588 & 653,588 & 653,588 & 653,588 & 653,588 & 653,588 & 653,588 \\
\hline$R^{2}$ & 0.015 & 0.091 & 0.198 & 0.176 & 0.016 & 0.091 & 0.198 & 0.176 \\
\hline & & Specifica & tion III & & & Specifico & tion $I V$ & \\
\hline & (1) & $(2)$ & $(3)$ & (4) & (1) & $(2)$ & $(3)$ & $(4)$ \\
\hline Trade & $6.84^{* *}$ & $3.68^{* *}$ & $3.36^{* *}$ & $2.41^{* *}$ & $6.85^{* *}$ & $3.65^{* *}$ & $3.33^{* *}$ & $2.42^{* *}$ \\
\hline & $(0.08)$ & $(0.10)$ & $(0.12)$ & $(0.12)$ & $(0.08)$ & $(0.11)$ & $(0.12)$ & $(0.12)$ \\
\hline Trade $\times$ Same Sector & - & - & - & - & $1.16+$ & $1.83^{*}$ & $2.28^{* *}$ & $1.95^{*}$ \\
\hline & - & - & - & - & $(0.62)$ & $(0.59)$ & $(0.55)$ & $(0.61)$ \\
\hline Trade $\times$ IO & $15.34^{* *}$ & $17.44^{* *}$ & $16.70^{* *}$ & $16.60^{* *}$ & $12.31^{* *}$ & $16.92^{* *}$ & $15.60^{* *}$ & $13.03^{* *}$ \\
\hline & $(1.38)$ & $(1.32)$ & $(1.27)$ & $(1.29)$ & $(2.10)$ & $(2.05)$ & $(2.04)$ & $(1.98)$ \\
\hline Trade $\times$ Same Sector $\times$ IO & - & - & - & - & 1.59 & -4.35 & $-5.14+$ & -0.52 \\
\hline & - & - & - & - & $(3.44)$ & $(3.26)$ & $(3.06)$ & $(3.24)$ \\
\hline Same Sector $\times$ IO & - & - & - & - & -46.42 & $-97.75^{*}$ & $-108.49^{*}$ & - \\
\hline & - & - & - & - & $(45.05)$ & $(42.31)$ & $(39.57)$ & - \\
\hline Same Sector & - & - & - & - & $46.68^{*}$ & $65.65^{* *}$ & $77.25^{* *}$ & - \\
\hline & - & - & - & - & $(17.27)$ & $(16.31)$ & $(15.12)$ & - \\
\hline Input-Output & $246.72^{* *}$ & $264.12^{* *}$ & $253.96^{* *}$ & - & $236.73^{* *}$ & $266.10^{* *}$ & $249.06^{* *}$ & - \\
\hline & $(17.87)$ & $(16.85)$ & $(16.12)$ & - & $(26.92)$ & $(26.11)$ & $(25.71)$ & - \\
\hline Observations & 653,588 & 653,588 & 653,588 & 653,588 & 653,588 & 653,588 & 653,588 & 653,588 \\
\hline$R^{2}$ & 0.016 & 0.092 & 0.198 & 0.176 & 0.016 & 0.092 & 0.198 & 0.176 \\
\hline$\mu_{c 1}+\mu_{c 2}+\mu_{i}+\mu_{j}$ & no & yes & no & no & no & yes & no & no \\
\hline$\mu_{c 1} \times \mu_{i}+\mu_{c 2} \times \mu_{j}$ & no & no & yes & no & no & no & yes & no \\
\hline$\mu_{c 1} \times \mu_{c 2}+\mu_{i} \times \mu_{j}$ & no & no & no & yes & no & no & no & yes \\
\hline
\end{tabular}

Notes: Robust standard errors in parentheses. ${ }^{* *}$ significant at $1 \% ;{ }^{*}$ significant at $5 \% ;+$ significant at $10 \%$. The sample period is 1970-99. The dependent variable is the correlation of the HP-filtered real output between sector $i$ and sector $j$ of the country pair. In all specifications, the trade variable is normalized by GDP. $\mu_{c 1}$ and $\mu_{c 2}$ are country 1 and 2 fixed effects, respectively. $\mu_{i}$ and $\mu_{j}$ are sector $i$ and $j$ fixed effects, respectively. Variable definitions and sources are described in detail in the text. 


\section{Appendix B Logs and Levels Estimates}

The estimation in the paper is carried out using logs of trade ratios on the right-hand side. The literature is split on whether logs or levels specification is more appropriate. While the original Frankel and Rose (1998) paper and several subsequent studies take logs, Kose and Yi (2006) use both levels and logs but argue that the levels specification has a more appealing quantitative interpretation. Thus, it is important to assess both which specification is favored by the data, and whether our results are robust to estimation in levels.

We chose the log specification as the baseline because the trade ratios in levels are extremely skewed, and thus a tiny share of the top values of the trade ratios affect the estimated coefficient a great deal. What the log specification does is reduce the influence of the largest trade values, providing a better fit for the data and more stable estimates. Table B1 reports the results of estimating the canonical Frankel-Rose regressions for the aggregate data in levels (Panel I) and in logs (Panel II). All the specifications include both sets of country effects. The first column reports the full sample estimates; the second column trims the most extreme $1 \%$ of the trade observations in the sample, the third column, $2.5 \%$ of the sample, the fourth, $5 \%$ of the sample, and the last column, $10 \%$ of the sample. In each case, following the best practice in the literature, we trim symmetrically on both ends (that is, in trimming $1 \%$, we remove $0.5 \%$ of the top trade observations, and $0.5 \%$ of the bottom). The results are striking. When just $1 \%$ of the observations are removed, the levels coefficient doubles, from 9.775 to 19.336. Even more problematically, trimming more data raises the coefficient even more, to $26.007,31.268$, and then 35.175 when $10 \%$ of the sample is dropped. This is clear evidence that the levels coefficient is unstable, taking different values at different points in the sample.

Remarkably, the same problem does not occur when using logs. Panel II reports the results. The coefficients are not sensitive to trimming, oscillating between 18.45 and 15.91, with the standard error of about 4 in each specification. ${ }^{1}$ Thus, the log specification appears

\footnotetext{
${ }^{1} \mathrm{As}$ in the main text, for ease of reading the tables and to reduce the number of decimal points, the regression coefficients and standard errors for the log (but not the level) regressions are multiplied by 1000.
} 
to capture adequately the strong nonlinearity in the data. ${ }^{2}$

The problem of unstable coefficients is not confined to the aggregate specifications. Table B2 reports the results of estimating the levels regression on the full sample (column 1), trimming the outlying $1 \%$ of the sample symmetrically (i.e. $0.5 \%$ from both the top and bottom of the distribution of the trade variable), trimming $2.5 \%$ of the sample, $5 \%$ of the sample, and $10 \%$ of the sample in successive columns. It is clear that the coefficients are very sensitive to the very top values. In the first panel, for example, while the full sample coefficient is 4.47 , losing the top $0.5 \%$ of trade observations raises it four-fold to 20.24 , top $1.25 \%$ to 30.7 , where it stays when the data are trimmed further. However, the first panel is by far the most stable. In all three of the other trade measures, the coefficients do not level off, rather they keep rising all the way up to the $10 \%$ trim. When trade is normalized by output, the coefficient starts out negative and significant, becomes insignificant when $2.5 \%$ of observations are removed, and then turns positive and significant for the $5 \%$ and $10 \%$ trims. In the other two specifications, the coefficient is positive and strongly significant throughout, but rises in magnitude for each successive trim of the data.

We also carried out the trimming exercise on a subsample that excludes the zero trade observations, reaching identical results. That is, the large differences in the levels coefficients (due to trimming) are not driven by zeros. Instead, they are driven by the largest trade observations. As a side note, none of the results appear to be affected by zeros, in the sense that in all cases, the levels coefficients with and without zeros in the sample are very similar.

Table B3 reports the same trimming exercise on logged trade data. It is remarkable that the coefficient is much more stable across all the untrimmed and trimmed samples, indicating that logging the trade variables downweights the extreme observations and thus makes the estimated coefficients more reliable throughout the sample.

\footnotetext{
${ }^{2}$ This in turn implies that the estimated magnitudes of the impact of trade on comovement are very sensitive to trimming in the levels specification, and are not sensitive in the log specification. Moving from the 25 th to the 75 th percentile in the distribution of the bilateral trade variable corresponds to the same change in trade in both the level and the log specifications (since the percentiles correspond to the same actual observations in both). Depending on the trimming, in the levels specification the change in left-hand side variable changes by a factor of 3.6 ; in the logs specification, the difference is only $12 \%$.
} 
While qualitatively the results are robust to estimating in levels, as we can see the estimated coefficients are unreliable. In addition, the stability of the log coefficients indicates that logging the trade variables adequately captures the nonlinearity present in the data. Thus, in the main text of the paper we we stick to the log specifications. However, it is still important to check that the results in levels are qualitatively robust. Tables B4 through B8 report all of the regression results in the paper using levels rather than logs (they are equivalent to Tables 1-5 in the main text of the paper). ${ }^{3}$ It is clear that all the results still hold. In particular, trade on its own is significant, and, more importantly, the interaction of bilateral trade with the I-O coefficient is always strongly significant as well.

\footnotetext{
${ }^{3}$ These tables use the sample trimming $2.5 \%$ of the observations $(5 \%$ in the case of Trade/Output, the most unstable coefficient). This is a relatively conservative trim.
} 
Table B1. Impact of Trade on Comovement at the Aggregate-Level: Trimming Exercise

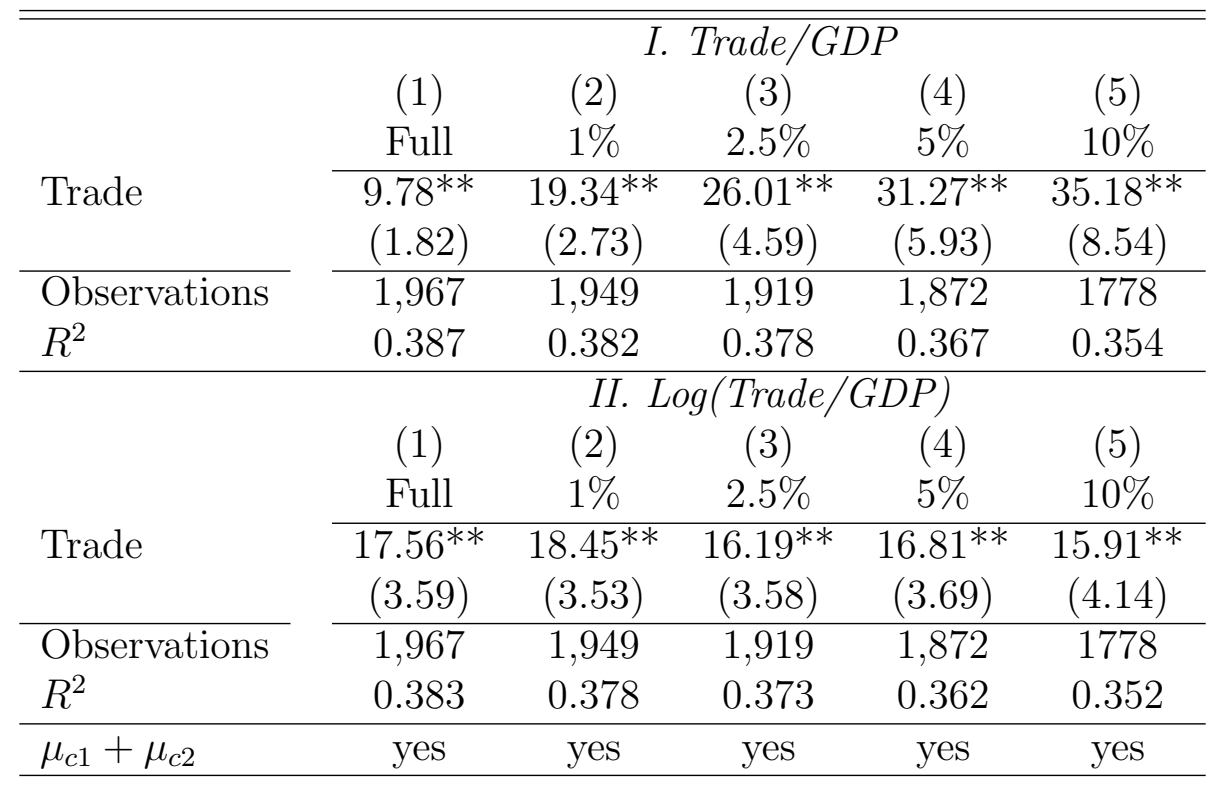

Notes: Robust standard errors in parentheses. ${ }^{* *}$ significant at $1 \%$; ${ }^{*}$ significant at $5 \%$; + significant at $10 \%$. The sample period is $1970-99$. The dependent variable is the correlation of the growth of real GDP. $\mu_{c 1}$ and $\mu_{c 2}$ denote the country fixed effects All specifications are estimated using OLS. 


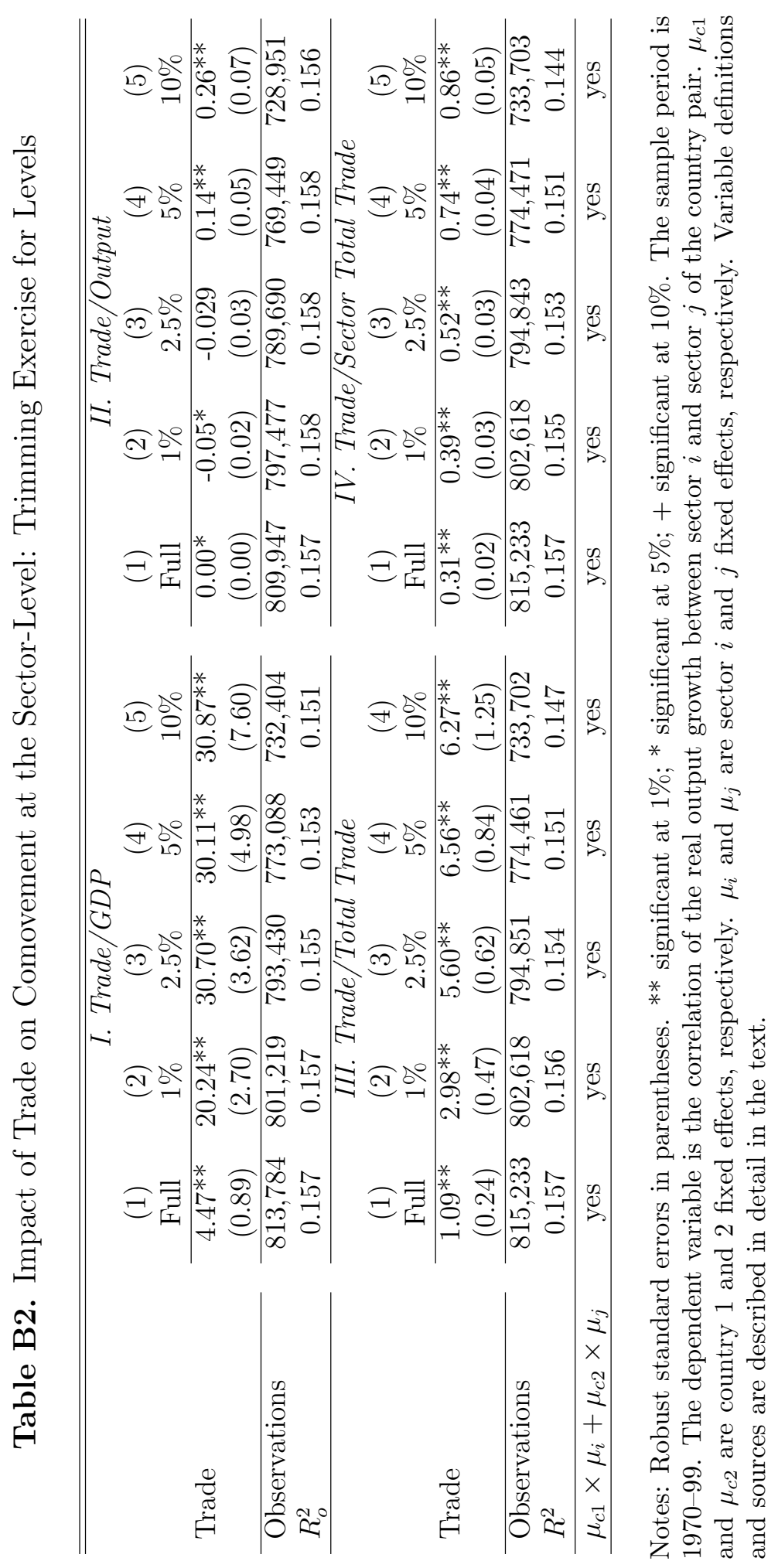




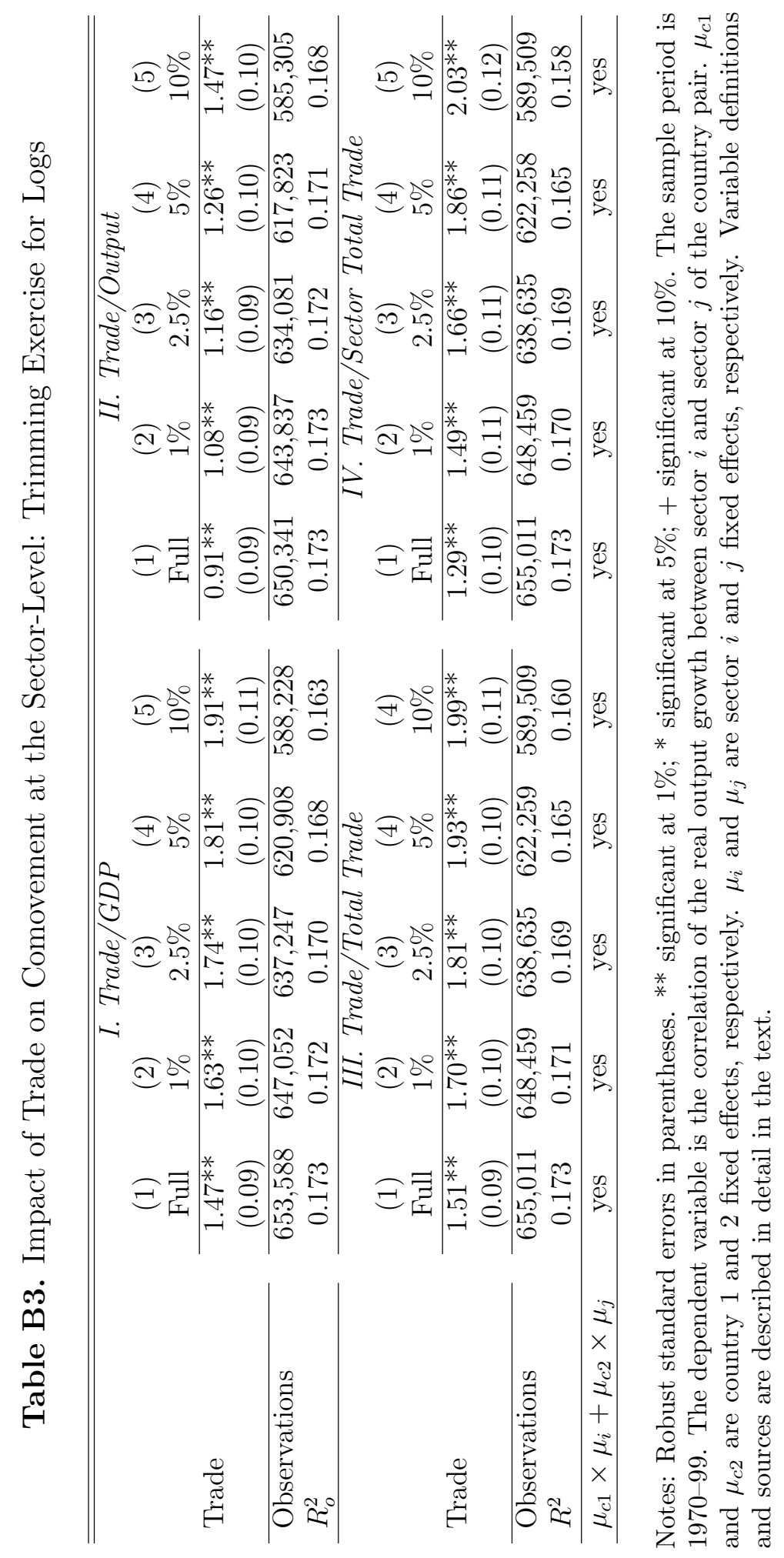




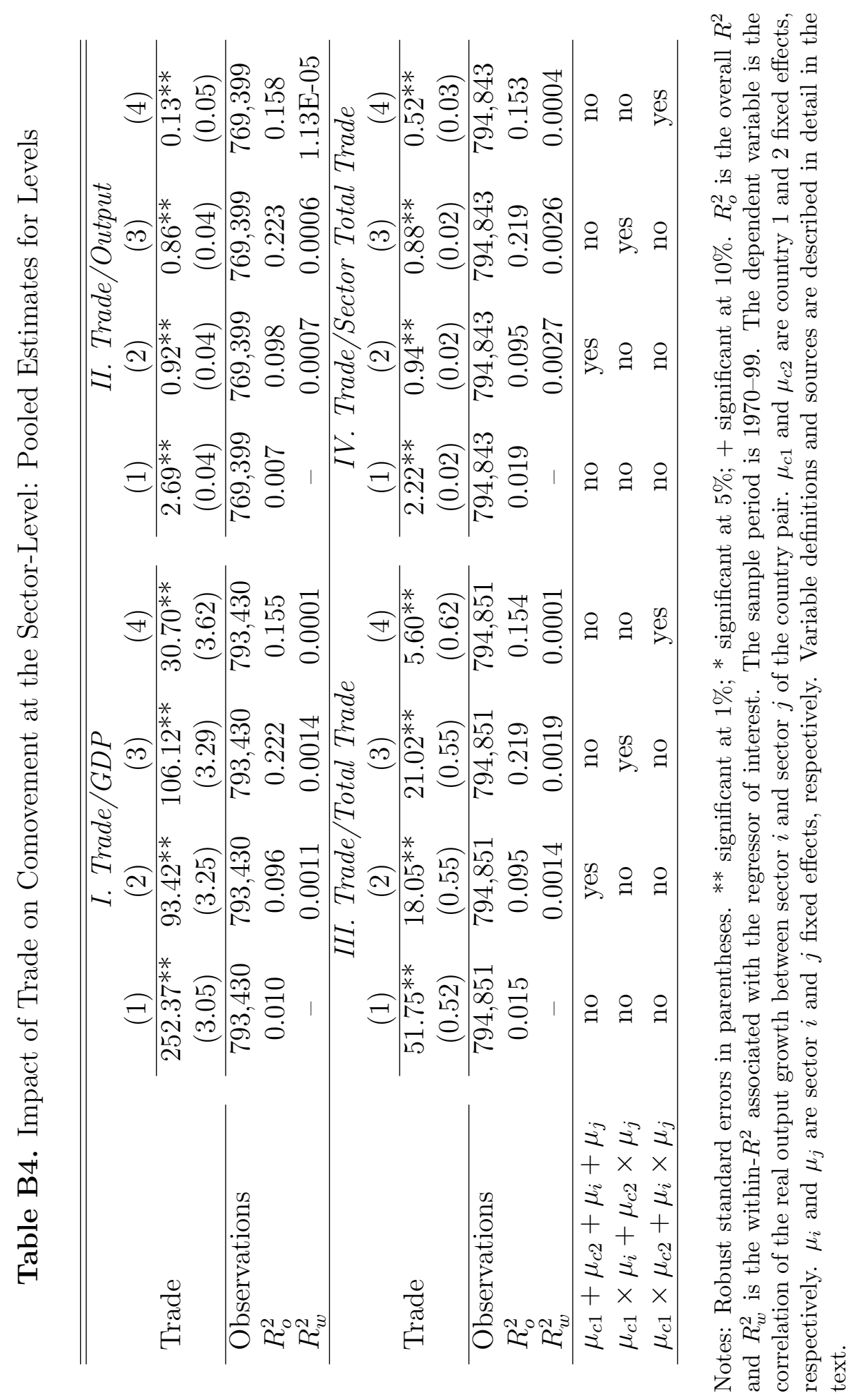




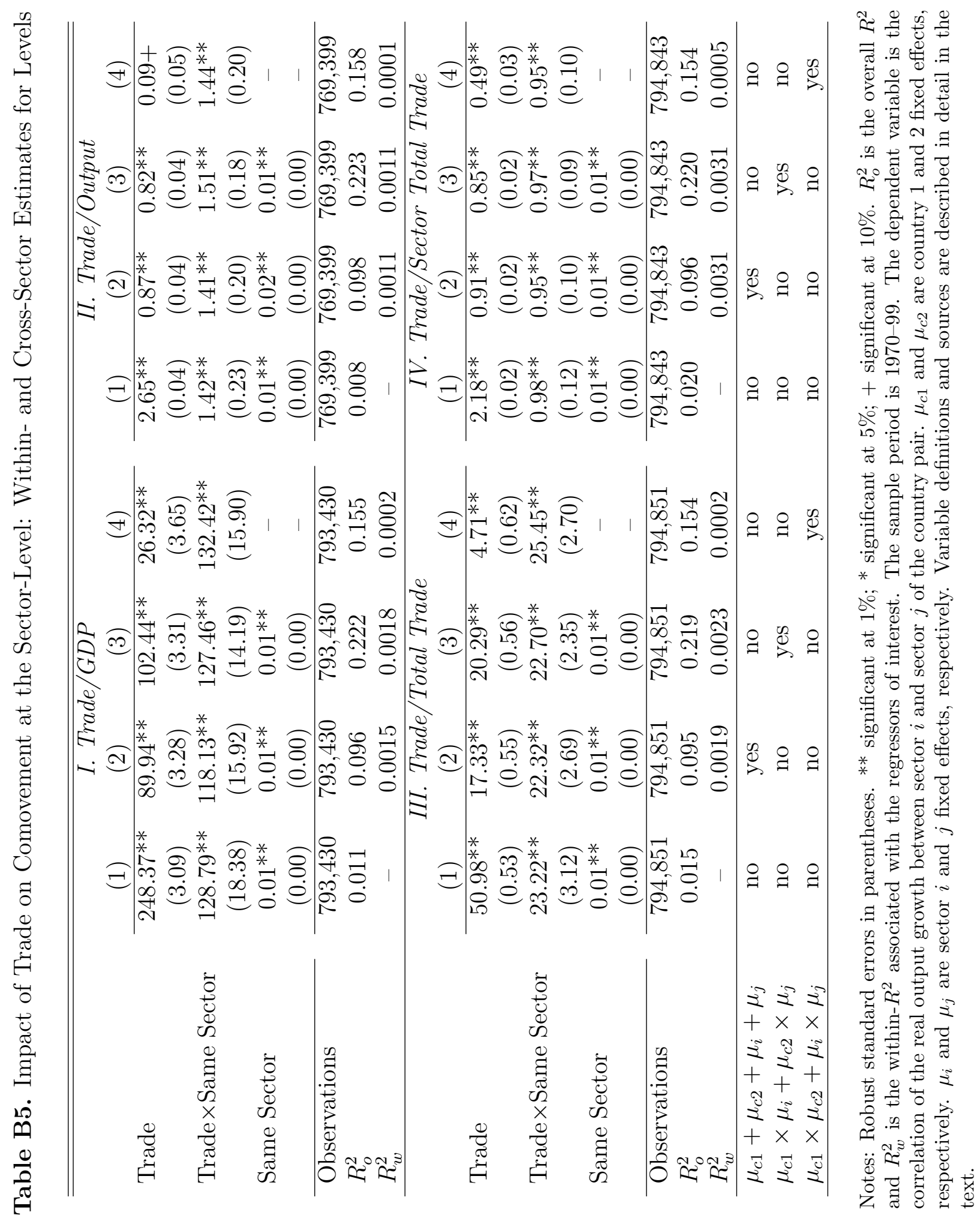




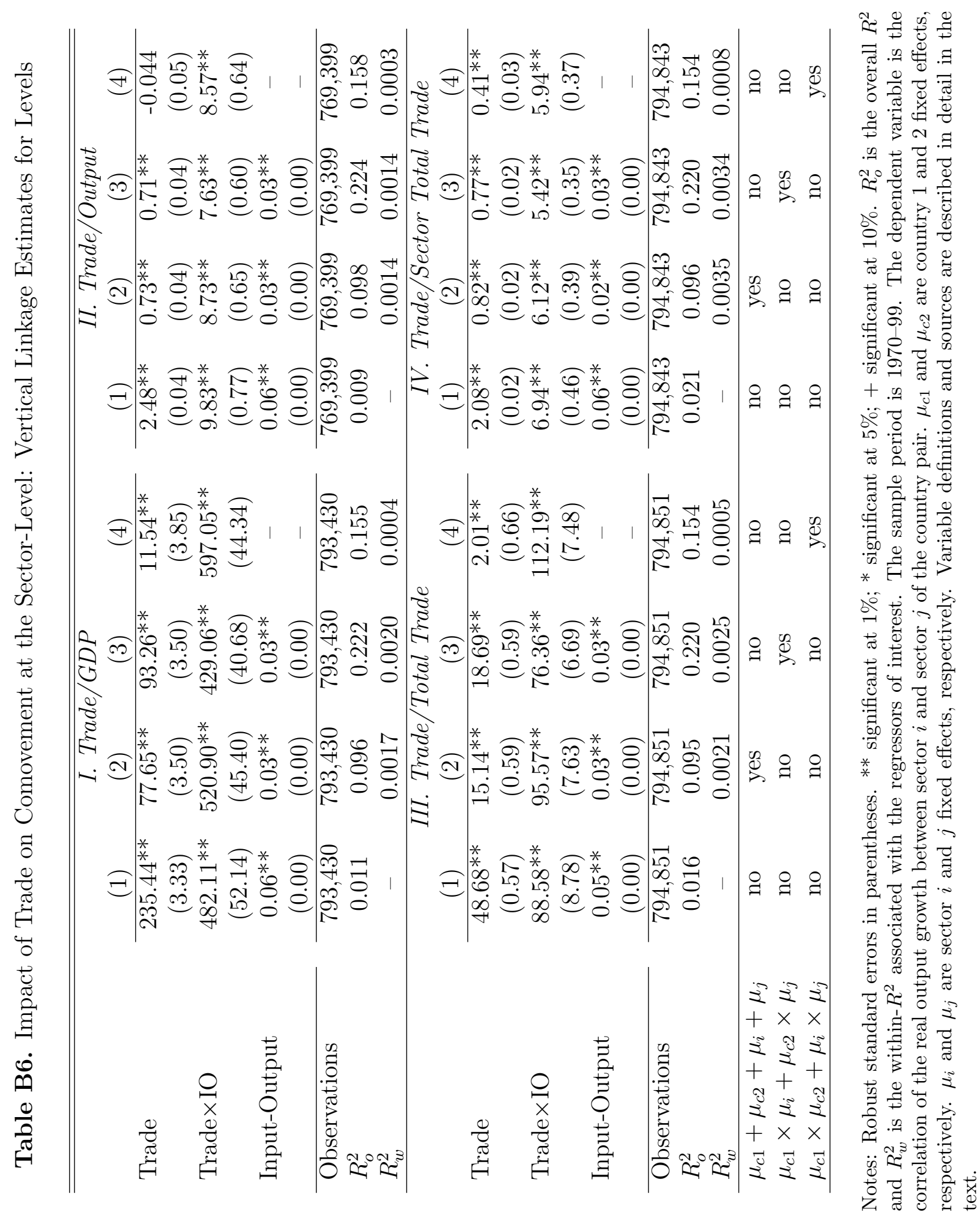


Table B7. Impact of Trade on Comovement at the Sector-Level: Vertical Linkages, Withinand Cross-Sector Estimates for Levels

\begin{tabular}{|c|c|c|c|c|c|c|c|c|}
\hline \multirow{4}{*}{ Trade } & \multicolumn{4}{|c|}{ I. Trade/GDP } & \multicolumn{4}{|c|}{ II. Trade/Output } \\
\hline & (1) & $(2)$ & $(3)$ & (4) & (1) & $(2)$ & (3) & $(4)$ \\
\hline & $48.33^{* *}$ & $14.68^{* *}$ & $18.43^{* *}$ & $1.64^{*}$ & $2.45^{* *}$ & $0.71^{* *}$ & $0.69^{* *}$ & -0.05 \\
\hline & $(0.58)$ & $(0.60)$ & $(0.60)$ & $(0.67)$ & $(0.04)$ & $(0.04)$ & $(0.04)$ & $(0.05)$ \\
\hline \multirow[t]{2}{*}{ Trade $\times$ Same Sector } & $16.10^{* *}$ & $16.54^{* *}$ & $19.94^{* *}$ & $15.80^{* *}$ & 0.0632 & 0.202 & $0.57^{*}$ & 0.20 \\
\hline & $(5.49)$ & $(4.77)$ & $(4.15)$ & $(4.81)$ & $(0.33)$ & $(0.30)$ & $(0.27)$ & $(0.30)$ \\
\hline \multirow[t]{2}{*}{ Trade $\times$ IO } & $95.64^{* *}$ & $113.09^{* *}$ & $78.68^{* *}$ & $126.68^{* *}$ & $12.11^{* *}$ & $10.13^{* *}$ & $8.25^{* *}$ & $9.26^{* *}$ \\
\hline & $(12.36)$ & $(10.78)$ & $(9.50)$ & $(10.65)$ & $(1.21)$ & $(1.00)$ & $(0.91)$ & $(0.97)$ \\
\hline \multirow[t]{2}{*}{ Trade $\times$ Same Sector $\times$ IO } & $-64.03^{* *}$ & $-76.82^{* *}$ & $-59.44^{* *}$ & $-72.59^{* *}$ & $-4.19^{*}$ & $-2.75+$ & $-2.50+$ & -1.81 \\
\hline & $(23.50)$ & $(20.31)$ & $(17.55)$ & $(20.18)$ & $(1.85)$ & $(1.59)$ & $(1.44)$ & $(1.56)$ \\
\hline \multirow{2}{*}{ Same Sector $\times$ IO } & $-0.07^{* *}$ & $-0.03 * *$ & $-0.04^{* *}$ & - & $-4.19 *$ & $-2.75+$ & $-2.50+$ & - \\
\hline & $(0.01)$ & $(0.01)$ & $(0.01)$ & - & $(1.85)$ & $(1.59)$ & $(1.44)$ & - \\
\hline \multirow[t]{2}{*}{ Same Sector } & $0.01^{* *}$ & $0.01^{* *}$ & $0.01 * *$ & - & $0.01^{* *}$ & $0.02^{* *}$ & $0.01^{* *}$ & - \\
\hline & $(0.00)$ & $(0.00)$ & $(0.00)$ & - & $(0.00)$ & $(0.00)$ & $(0.00)$ & - \\
\hline \multirow[t]{2}{*}{ Input-Output } & $0.10^{* *}$ & $0.04^{* *}$ & $0.04^{* *}$ & - & $0.12^{* *}$ & $0.04^{* *}$ & $0.04^{* *}$ & - \\
\hline & $(0.00)$ & $(0.00)$ & $(0.00)$ & - & $(0.00)$ & $(0.00)$ & $(0.00)$ & - \\
\hline Observations & 794,851 & 794,851 & 794,851 & 794,851 & 769,399 & 769,399 & 769,399 & 769,399 \\
\hline$R_{o}^{2}$ & 0.016 & 0.095 & 0.220 & 0.154 & 0.009 & 0.099 & 0.224 & 0.158 \\
\hline \multirow[t]{3}{*}{$R_{w}^{2}$} & - & 0.0019 & 0.0021 & 0.0004 & - & 0.0016 & 0.0015 & 0.0003 \\
\hline & \multicolumn{4}{|c|}{ III. Trade/Total Trade } & \multicolumn{4}{|c|}{ IV. Trade/Sector Total Trade } \\
\hline & (1) & $(2)$ & (3) & (4) & (1) & $(2)$ & $(3)$ & $(4)$ \\
\hline \multirow[t]{2}{*}{ Trade } & $48.33^{* *}$ & $14.68^{* *}$ & $18.43^{* *}$ & $1.64^{*}$ & $2.04^{* *}$ & $0.79^{* *}$ & $0.75^{* *}$ & $0.39^{* *}$ \\
\hline & $(0.58)$ & $(0.60)$ & $(0.60)$ & $(0.67)$ & $(0.02)$ & $(0.02)$ & $(0.02)$ & $(0.03)$ \\
\hline \multirow[t]{2}{*}{ Trade $\times$ Same Sector } & $16.10^{* *}$ & $16.54^{* *}$ & $19.94^{* *}$ & $15.80^{* *}$ & 0.428 & $0.48^{* *}$ & $0.64^{* *}$ & $0.46^{* *}$ \\
\hline & $(5.49)$ & $(4.77)$ & $(4.15)$ & $(4.81)$ & $(0.18)$ & $(0.15)$ & $(0.13)$ & $(0.15)$ \\
\hline \multirow{2}{*}{ Trade $\times$ IO } & $95.64^{* *}$ & $113.09^{* *}$ & $78.68^{* *}$ & $126.68^{* *}$ & $9.36^{* *}$ & $8.06^{* *}$ & $6.90^{* *}$ & $7.47^{* *}$ \\
\hline & $(12.36)$ & $(10.78)$ & $(9.50)$ & $(10.65)$ & $(0.70)$ & $(0.58)$ & $(0.52)$ & $(0.57)$ \\
\hline \multirow[t]{2}{*}{ Trade $\times$ Same Sector $\times$ IO } & $-64.03^{* *}$ & $-76.82^{* *}$ & $-59.44^{* *}$ & $-72.59^{* *}$ & $-5.36^{* *}$ & $-4.62^{* *}$ & $-4.38^{* *}$ & $-3.91^{* *}$ \\
\hline & $(23.50)$ & $(20.31)$ & $(17.55)$ & $(20.18)$ & $(1.08)$ & $(0.92)$ & $(0.80)$ & $(0.89)$ \\
\hline \multirow[t]{2}{*}{ Same Sector $\times$ IO } & $-0.07^{* *}$ & $-0.03^{* *}$ & $-0.04^{* *}$ & - & $-0.07^{* *}$ & $-0.03^{* *}$ & $-0.03^{* *}$ & - \\
\hline & $(0.01)$ & $(0.01)$ & $(0.01)$ & - & $(0.01)$ & $(0.01)$ & $(0.01)$ & - \\
\hline \multirow[t]{2}{*}{ Same Sector } & $0.01^{* *}$ & $0.01^{* *}$ & $0.01^{* *}$ & - & 0.001 & $0.01^{* *}$ & $0.01^{* *}$ & - \\
\hline & $(0.00)$ & $(0.00)$ & $(0.00)$ & - & $(0.00)$ & $(0.00)$ & $(0.00)$ & - \\
\hline \multirow[t]{2}{*}{ Input-Output } & $0.10^{* *}$ & $0.04^{* *}$ & $0.04^{* *}$ & - & $0.11^{* *}$ & $0.03^{* *}$ & $0.03^{* *}$ & - \\
\hline & $(0.00)$ & $(0.00)$ & $(0.00)$ & - & $(0.00)$ & $(0.00)$ & $(0.00)$ & - \\
\hline Observations & 794,851 & 794,851 & 794,851 & 794,851 & 794,843 & 794,843 & 794,843 & 794,843 \\
\hline$R_{o}^{2}$ & 0.016 & 0.095 & 0.220 & 0.154 & 0.022 & 0.096 & 0.220 & 0.154 \\
\hline$R_{w}^{2}$ & - & 0.0022 & 0.0026 & 0.0005 & - & 0.0037 & 0.0036 & 0.0009 \\
\hline$\mu_{c 1}+\mu_{c 2}+\mu_{i}+\mu_{j}$ & no & yes & no & no & no & yes & no & no \\
\hline$\mu_{c 1} \times \mu_{i}+\mu_{c 2} \times \mu_{j}$ & no & no & yes & no & no & no & yes & no \\
\hline$\mu_{c 1} \times \mu_{c 2}+\mu_{i} \times \mu_{j}$ & no & no & no & yes & no & no & no & yes \\
\hline
\end{tabular}

Notes: Robust standard errors in parentheses. ${ }^{* *}$ significant at $1 \% ;{ }^{*}$ significant at $5 \%$; + significant at $10 \% . R_{o}^{2}$ is the overall $R^{2}$ and $R_{w}^{2}$ is the within- $R^{2}$ associated with the regressors of interest. The sample period is 1970-99. The dependent variable is the correlation of the real output growth between sector $i$ and sector $j$ of the country pair. $\mu_{c 1}$ and $\mu_{c 2}$ are country 1 and 2 fixed effects, respectively. $\mu_{i}$ and $\mu_{j}$ are sector $i$ and $j$ fixed effects, respectively. Variable definitions and sources are described in detail in the text. 
Table B8. Impact of Trade on Comovement at the Sector-Level: Vertical Linkages and Elasticities of Substitution Estimates for Levels

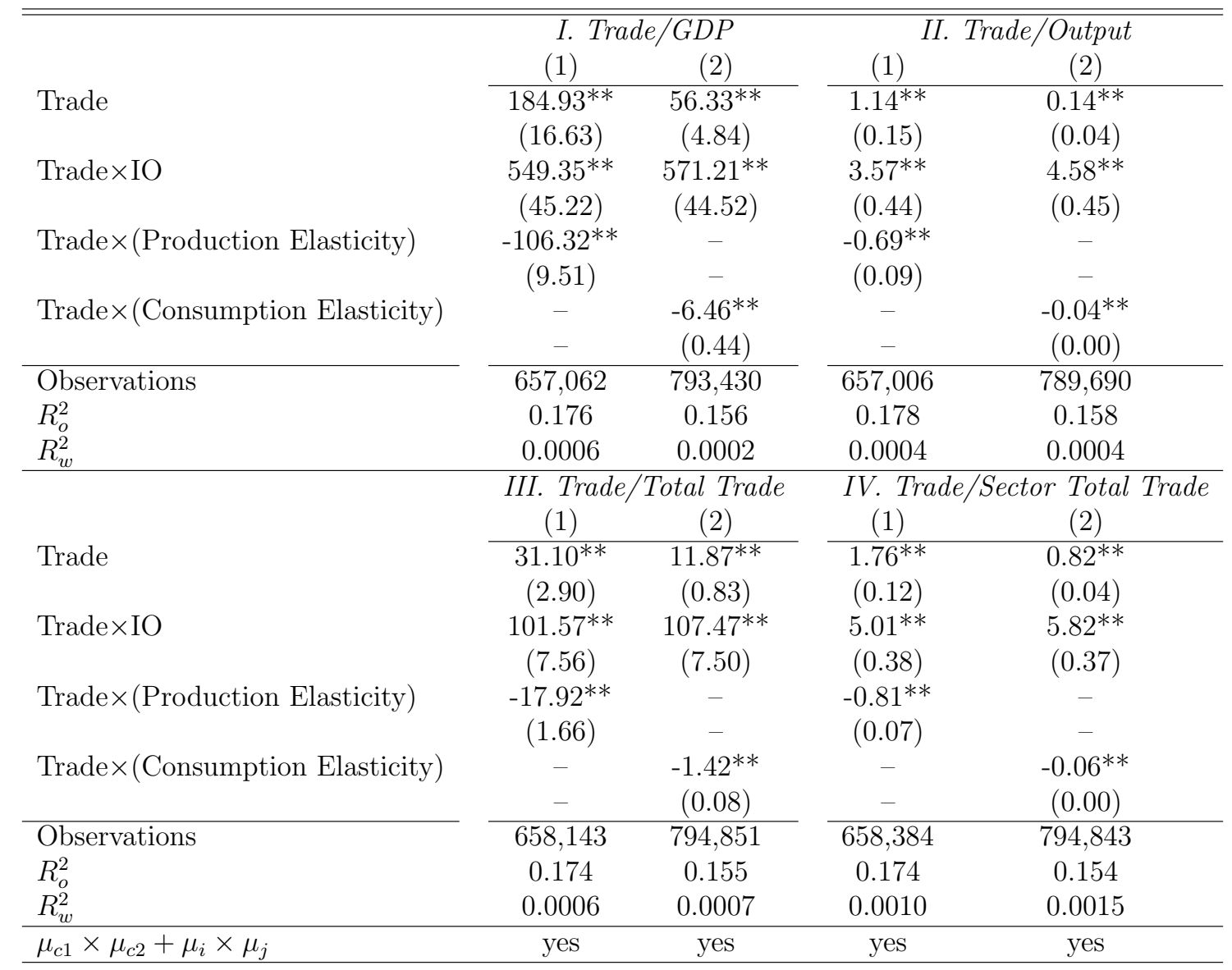

Notes: Robust standard errors in parentheses. ${ }^{* *}$ significant at $1 \%$; ${ }^{*}$ significant at $5 \% ;+$ significant at $10 \% . R_{o}^{2}$ is the overall $R^{2}$ and $R_{w}^{2}$ is the within- $R^{2}$ associated with the regressors of interest. The sample period is 1970-99. The dependent variable is the correlation of the real output growth between sector $i$ and sector $j$ of the country pair. $\mu_{c 1}$ and $\mu_{c 2}$ are country 1 and 2 fixed effects, respectively. Production Elasticity taken from Luong (2008), and Consumption Elasticity taken from Broda and Weinstein (2006). $\mu_{i}$ and $\mu_{j}$ are sector $i$ and $j$ fixed effects, respectively. Variable definitions and sources are described in detail in the text. 


\section{References}

Frankel, Jeffrey A. and Andrew K. Rose, "The Endogeneity of the Optimum Currency Area Criteria," Economic Journal, July 1998, 108 (449), 1009-25.

Kose, M. Ayhan and Kei-Mu Yi, "Can the Standard International Business Cycle Model Explain the Relation Between Trade and Comovement?," Journal of International Economics, March 2006, 68 (2), 267-95. 